\title{
KOMPARASI PERSEPSI KEPUASAN TAMU SECARA LISAN DAN TERTULIS KETIKA MENGINAP DI HOTEL BINTANG EMPAT
}

\author{
Dian Tiur Ulina Pakpahan', A.H.G Kusumah² ${ }^{*}$ Rosita $^{3}$ \\ 1,2,3 Universitas Pendidikan Indonesia Bandung \\ Email: 2galih@upi.com \\ *Penulis korespondensi
}

\begin{abstract}
Abstrak
Kepuasan akan terjadi ketika harapan yang terbentuk sesuai dan/atau melebihi kenyataan yang diterima. Begitu pun sebaliknya, ketika harapan yang terbentuk tidak sesuai dengan kenyataan yang diterima akan menimbulkan ketidakpuasan. Penelitian ini bertujuan untuk mengetahui dan membandingkan kepuasan dan ketidakpuasan tamu secara tertulis dan lisan pada hotel bintang empat di Bandar Lampung. Penelitian ini merupakan penelitian deskriptif dan menggunakan pendekatan kualitatif, dengan teknik purposive sampling. Sumber data yang digunakan dalam penelitian ini adalah data sekunder berupa ulasan online dan data primer berupa hasil wawancara dengan narasumber. Dalam penelitian ini, ulasan online yang terkumpul berasal dari situs TripAdvisor dan Google Review dengan jumlah 104 ulasan dari lima hotel bintang empat yang ada di Bandar Lampung. Sedangkan narasumber terdiri dari 14 orang dengan kriteria sudah pernah menginap minimal di salah satu hotel bintang empat di Bandar Lampung. Hasil dari penelitian ini yaitu terdapat perbedaan kepuasan dan ketidakpuasan tamu jika disampaikan secara tertulis dan lisan. Elemen yang bisa memberikan kepuasan dan ketidakpuasan untuk tamu lebih banyak ditemukan saat disampaikan secara lisan. Ketika menyampaikan melalui tulisan, tamu cenderung menyampaikannya secara singkat, tetapi ketika menyampaikan kepuasan dan ketidakpuasannya secara lisan, tamu dirasa lebih detail menyampaikan keseluruhan pengalamannya. Namun, ketika menyampaikan secara lisan, tamu cenderung lebih sering menyampaikan kepuasan dibandingkan ketidakpuasan. Untuk itu, diharapkan untuk pihak manajemen hotel bintang empat di Bandar Lampung agar secara berkala melakukan survei secara langsung kepada tamu yang sedang menginap untuk mengetahui kepuasan dan ketidakpuasan yang dirasakan sehingga bisa mempertahankan elemen yang sudah baik dan memperbaiki elemen yang dianggap masih kurang.
\end{abstract}

Kata kunci: Komparasi; kepuasan; ketidakpuasan; tertuli; lisan; hotel bintang empat; bandar lampung.

\begin{abstract}
Satisfaction is achieved when reality exceed guest expectations. Likewise, when there is a gap between expectations and the reality, it can lead into dissatisfaction. This study aims to compare guest's satisfaction and dissatisfaction on a written and oral basis at four-star hotels in Bandar Lampung. This research is based on descriptive study and uses a qualitative approach, with a purposive sampling technique. The data sources used in this study are secondary data in the form of online reviews and primary data in the form of interviews with persons. In this study, the online reviews collected were from the TripAdvisor site and Google Review with 104 reviews from five four-star hotels in Bandar Lampung. Meanwhile, the speakers are consisted of 14 people with the criteria that they had stayed at a minimum in one of the four-star hotels in Bandar Lampung. The results of this study are various in guest's satisfaction and dissatisfaction if they are delivered writtenly and orally. Things that can provide guest's satisfaction and dissatisfaction are found more when they are delivered orally. When conveying through writing, guests tend to convey it briefly, but when conveying their satisfaction and dissatisfaction orally, guests give more detailed conveying their overall experience. However, when delivering orally, guests tend to convey satisfaction more often than dissatisfaction. For this reason, it is expected that the management of fourstar hotels in Bandar Lampung to periodically conduct surveys directly to guests who are staying to find out satisfaction and dissatisfaction "feel" so that they can maintain the good things and fix things that are considered still lacking.
\end{abstract}

Keywords: Comparison; satisfaction; dissatisfaction; written; oral; fourstar hotel; bandar lampung.

\section{PENDAHULUAN}

Pada umumnya, setiap orang memiliki keinginan dan kebutuhan yang berbeda-beda dan mereka memiliki acuan tersendiri untuk menentukan apakah mereka puas atau tidak puas. Bagi manajemen hotel, sangatlah penting memahami kepuasan dan ketidakpuasan tamu karena tingkat kepuasan tamu dapat berdampak pada tingkat hunian hotel yang pada akhirnya akan berpengaruh terhadap pendapatan hotel. Salah satu cara untuk memahami kepuasan tamu terhadap suatu hotel dapat dilakukan melalui 
peninjauan terhadap komentar yang ditulis tamu pada platform website tinjauan perjalanan seperti tripadvisor. Saat ini tripadvisor merupakan salah satu media yang paling berpengaruh dan mudah diakses sebagai situs ulasan bagi tamu setelah menginap di sebuah hotel (Xiang \& Gretzel, 2010). Website sejenis yang juga cukup popular adalah Google Review. Melalui TripAdvisor dan Google Review, kita bisa membaca ulasan yang pernah dituliskan oleh para pengguna lainnya tentang pengalaman mereka mengenai tempat yang pernah mereka datangi dan layanan yang pernah mereka rasakan, maka pengguna lain yang ingin berpergian bisa melakukan pertimbangan dilihat dari komentar positif dan negatif yang ada.

Selain melalui peninjauan ulasan online yang dituliskan tamu, terdapat cara lain untuk mengetahui bagaimana tamu menyampaikan tentang kepuasan dan ketidakpuasan yang dirasakannya, yaitu secara lisan. Tamu dapat menyampaikan secara langsung tentang keluhan dan saran yang dialaminya kepada pihak hotel. Ataupun sebaliknya, dimana hotel bertanya secara langsung pada tamu sejauh mana kepuasan yang tamu rasakan atas keseluruhan pelayanan yang hotel berikan.

Walaupun kepuasan dan ketidakpuasan tamu ketika menginap di hotel dapat disampaikan baik melalui komentar tertulis maupun komentar lisan, namun cara penyampaian dan penekanan konten sangat mungkin berbeda. Memahami perbedaan bagaimana tamu hotel menyampaikan ekspresi kepuasannya secara lisan dan tertulis sangatlah penting agar pihak hotel mampu bereaksi dan merespon secara tepat setiap ekspresi pengalaman yang disampaikan oleh tamu baik melalui lisan maupun tertulis. Penelitian ini bertujuan untuk mengetahui dan membandingkan kepuasan dan ketidakpuasan tamu secara tertulis dan lisan pada hotel bintang empat.

\section{TINJAUAN PUSTAKA}

\section{Kepuasan Tamu}

Kata kepuasan (satisfaction) berasal dari kata Latin "satis" yang berarti cukup baik, memadai dan "facio" yang berarti melakukan atau membuat. Kepuasan bisa diartikan sebagai "upaya pemenuhan sesuatu" atau "membuat sesuatu memadai" (Tjiptono \& Chandra, 2011). Kepuasan ditentukan oleh ekspektasi dan persepsi pelanggan dan jika manfaat lebih kecil dari harapan maka pelanggan tidak akan puas dan tidak senang. Begitu juga ketika manfaat sesuai dengan harapan maka pelanggan akan merasa senang.

Lupiyoadi menyebutkan lima faktor utama yang perlu diperhatikan dalam kaitannya dengan kepuasan konsumen, antara lain (Lupiyoadi, 2001):
1) Kualitas Produk

Konsumen akan puas bila hasil evaluasi mereka menunjukkan bahwa produk yang mereka gunaan berkualitas. Produk dikatakan berkualitas bagi seseorang, jika produk itu dapat memenuhi kebutuhannya (Lupiyoadi, 2001). Kualitas produk ada dua yaitu eksternal dan internal. Salah satu kualitas produk dari faktor eksternal adalah citra merek.

2) Kualitas Pelayanan

Konsumen akan merasa puas bila mendapatkan pelayanan yang baik atau yang sesuai dengan harapan.

3) Emosional

Konsumen merasa puas ketika orang memuji dia karena menggunakan merek yang mahal.

4) Harga

Produk yang mempunyai kualitas yang sama tetapi menetapkan harga yang relatif murah akan memberikan nilai yang lebih tinggi.

5) Biaya

Konsumen yang tidak perlu mengeluarkan biaya tambahan atau tidak perlu membuang waktu untuk mendapatkan suatu produk atau jasa cenderung puas terhadap produk atau jasa tersebut.

\section{Ketidakpuasan Tamu}

Kata ketidakpuasan bisa berarti ketika harapan yang terbentuk tidak sesuai dengan kenyataan yang terjadi. Pemasaran tidak hanya berorientasi ke arah kepuasan, tetapi juga terhadap ketidakpuasan manajemen dan penanganan keluhan (Vela'zquez, Beatriz, Marı'a, Irene, \& Gloria, 2010). Penanganan pelayanan yang efektif dapat mengubah konsumen dan memberikan peluang untuk mengubah pelanggan yang tidak puas menjadi puas (Artanti \& Lestari, 2010). Keluhan adalah sebagai salah satu metode yang digunakan pelanggan untuk menunjukkan ketidakpuasan yang menjadi titik awal dari perilaku mengeluh (Emir, 2011). Keluhan pelanggan sangat penting untuk perusahaan karena memberikan kesempatan untuk perusahaan agar mampu memperbaiki kesalahan yang dihadapi selama memberikan layanan (Lam \& Tang, 20013).

Faktor-faktor yang dapat membuat tamu merasa tidak puas adalah fasilitas rekreasi, program bagi traveler, penanganan bagasi, kolam berenang dan gym, ruang pertemuan, pemandangan lingkungan sekitar, transportasi, sistem reservasi, keamanan, laundry, dan nilai uang (Heung, 2000). Sedangkan ada pernyataan lain yang menyatakan bahwa kebersihan, kamar, pelayanan, makanan, tempat tidur, perlengkapan kamar mandi, karyawan yang tidak ramah, suasana 
yang bising, ukuran kamar, ukuran kamar yang kecil, dan harga yang mahal namun dengan kualitas yang rendah merupakan faktor-faktor yang seringkali membuat tamu merasa kecewa dan tidak puas (Dolnicar, 2002).

\section{METODE PENELITIAN}

Penelitian ini merupakan penelitian deskriptif dengan pendekatan kualitatif. Tujuan peneliti menggunakan penelitian deskriptif dengan menggunakan pendekatan kualitatif adalah menggali secara lebih dalam mengenai kepuasan dan ketidakpuasan tamu pada hotel bintang empat di Bandar Lampung, baik secara tertulis dan lisan lalu membandingkannya karena peneliti memiliki asumsi bahwa dipercaya adanya perbedaan kepuasan dan ketidakpuasan pada tamu serta cara tamu menyampaikannya, baik secara tertulis, yaitu melalui ulasan online dan secara tertulis, yaitu melalui wawancara secara langsung dengan tamu.

Penelitian ini dilakukan di Kota Bandar Lampung. Penentuan subjek penelitian dilakukan dengan menggunakan teknik purposive sampling, yaitu menentukan subjek dengan kriteria tertentu. Peneliti melakukan pengumpulan data melalui pengambilan ulasan online dari TripAdvisor dan Google Review, juga wawancara yang dilakukan dari satu narasumber ke narasumber lain yang memenuhi kriteria hingga mengalami titik jenuh. Adapun kriteria narasumber yang ditentukan adalah pengulas yang sudah menginap di salah satu hotel bintang empat di Bandar Lampung, antara lain Hotel Novotel Lampung, Emersia Hotel dan Resort, Swiss-Belhotel Lampung, Sheraton Lampung Hotel, dan Bukit Randu Hotel \& Restaurant, dan juga sudah menuliskan sebuah ulasan tentang hotel tersebut di TripAdvisor atau Google Review untuk mengetahui dan mendapatkan data tentang apa saja yang menentukan kepuasan dan ketidakpuasan tamu. Setelah itu untuk membandingkan hasil data yang telah didapatkan dari ulasan, peneliti akan mencari dan mewawancarai narasumber dengan kriteria pernah menginap minimal satu malam di salah satu hotel bintang empat di Bandar Lampung sebagai subjek penelitian. Peneliti juga mewawancarai narasumber yang sudah pernah menginap di hotel bintang empat di Bandar Lampung. Dari situs ulasan TripAdvisor dan Google Review, peneliti mendapatkan 104 ulasan dari kelima hotel bintang empat di Bandar Lampung, serta mewawancarai 14 narasumber.

Analisis data dilakukan dengan cara melakukan pengkategorian dan didapatkan beberapa kepuasan dan ketidakpuasan, setelah itu peneliti membuat code berdasarkan ulasan tamu. Setiap pernyataan dimasukkan kedalam tabel tabulasi data sesuai dengan kepuasan dan ketidakpuasan yang ada, membuat analisis awal, menghitung persentase dari setiap penentu, membuat analisis akhir dalam bentuk grafik, serta membuat diagram titik singgung untuk mengetahui apakah ada persamaan kepuasan dan ketidakpuasan. Untuk membandingkan hasilnya, peneliti melakukan langkah yang sama dengan hasil wawancara dan melihat apakah ada perbandingan kepuasan dan ketidakpuasan yang disampaikan secara tertulis dan lisan.

\section{HASIL PENELITIAN DAN PEMBAHASAN}

Pada penelitian ini, peneliti ingin mengetahui bagaimana kepuasan dan ketidakpuasan tamu pada hotel bintang di Bandar Lampung, yang disampaikan secara tertulis, yaitu melalui ulasan online, lalu membandingkannya dengan hasil kepuasan dan ketidakpuasan yang disampaikan secara lisan, yaitu melalui wawancara.

\section{Secara Tertulis (Ulasan Online)}

Dalam semua ulasan yang terkumpul dari Trip Advisor dan Google Review, terdapat 104 ulasan dari kelima hotel, yaitu 45 ulasan dengan persentase 43,27\% bersumber dari TripAdvisor dan 59 ulasan dengan persentase $56,73 \%$ bersumber dari Google Review. Dari semua hasil data berupa ulasan yang telah dikumpulkan, peneliti menemukan adanya 19 elemen yang terdiri dari 11 elemen yang memberikan kepuasan, yaitu sikap dan kinerja staf, lokasi, kamar, atmosfer, fasilitas, pelayanan, harga, makanan, keamanan, rekreasi dan hiburan, serta delapan elemen yang menimbulkan ketidakpuasan, yaitu sikap dan kinerja staf, kebersihan, pelayanan, makanan, kamar, fasilitas, keamanan, dan atmosfer.

\section{Kepuasan Tamu}

Setelah mengetahui adanya 11 elemen yang dapat memberikan kepuasan untuk tamu, selanjutnya peneliti menghitung persentase dari setiap elemen, dimana didapatkan hasil bahwa atmosfer merupakan elemen yang paling sering disebutkan oleh tamu dalam memberikan kepuasan dengan persentase $22,88 \%$, setelah itu ada ada fasilitas di 13,56\%, lalu arsitektur di $11,86 \%$, sikap dan kinerja staf di $10,17 \%$, selanjutnya terdapat dua kepuasan yang memiliki nilai persentase yang sama di 8,48\% yaitu kamar dan pelayanan, lalu ada lokasi di 7,63\%, makanan di 6,78\%, harga di $5,08 \%$, rekreasi dan hiburan di 3,39\%, dan yang terakhir pemberi kepuasan dengan nilai persentase 
terendah di 1,69\% yaitu keamanan. Beberapa elemen kepuasan yang seringkali menjadi sorotan tamu adalah sikap dan kinerja staf yang menyangkut elemen keramahtamahan dan respon dalam membantu tamu. Elemen ini didukung oleh penelitian sebelumnya yang mengatakan bahwa karyawan yang dapat memberikan pelayanan dengan cepat, memiliki jiwa hospitality yang tinggi membuat tamu merasa nyaman dan aman saat berkunjung. Namun untuk meningkatkan lagi kepuasan tamu, realibility (kehandalan) karyawan perlu ditingkatkan lagi (Rosita, Marhanah, \& Wahadi, 2016). Selain itu juga ada pelayanan yang biasanya selalu berkaitan dengan elemen lainnya, seperti layanan yang dijanjikan, kesediaan untuk membantu, kompetensi, respon yang empatik, serta penampilan, dan sub-atribut yang paling signifikan dalam memberikan kepuasan bagi tamu adalah adanya respon yang empatik dalam memberikan jasa yang terbaik untuk tamu (Palupi, Kusumah, \& Rosita, 2018).

\section{Ketidakpuasan Tamu}

Selanjtunya peneliti juga melakukan elemen yang sama untuk ketidakpuasan tamu, dimana setelah mendapatkan adanya delapan elemen pemberi ketidakpuasan, peneliti juga menghitung persentase dari setiap elemen dan didapatkan elemen yang paling sering disebutkan oleh tamu, yaitu kamar dengan persentase $20 \%$, lalu ada fasilitas di $18,18 \%$, selanjutnya terdapat juga penentu ketidakpuasan dengan nilai persentase yang sama di $16,36 \%$ yaitu sikap dan kinerja staf, dan pelayanan, setelah itu ada kebersihan di $12,73 \%$, makanan di $7,27 \%$, atmosfer di $5,45 \%$, dan yang terakhir yaitu keamanan di 3,64\% dengan nilai persentase terendah.

Dari semua elemen-elemen pemberi kepuasan dan ketidakpuasan, terdapat tujuh elemen yang memiliki kesamaan antara kepuasan dan ketidakpuasan pada tamu hotel bintang empat di Bandar Lampung, yaitu kamar, fasilitas, sikap dan kinerja staf, pelayanan, makanan, atmosfer, dan keamanan. Selain itu, peneliti juga menemukan bagaimana cara pengulas melalui ulasan online menyampaikan kepuasan dan ketidakpuasan yang mereka rasakan. Peneliti melihat dan memiliki pendapat bahwa ketika seseorang menyampaikan apa yang dirasakan setelah menginap di sebuah hotel, terutama saat mendapatkan kepuasan, secara umum mereka cenderung hanya menyampaikan poinpoin pentingnya saja, tanpa menjelaskan secara detail apa penyebab dari kepuasan yang didapatkan, tetapi berbeda ketika menyampaikan ketidakpuasan. Tamu cenderung menuliskan secara detail tentang ketidakpuasan yang mereka dapatkan. Elemen ini dirasa bisa terjadi karena seorang pengulas ingin membagikan pengalamannya ke orang lain yang akan membaca, berharap orang lain dapat belajar dari pengalaman buruk yang mereka dapatkan, sehingga bisa lebih mempertimbangkan jika ingim memilih hotel. Selain itu, dirasa ada beberapa orang yang menuliskan keluhan mereka secara detail agar pihak hotel yang membacanya bisa memperbaiki kualitas dari hotel tersebut dan bisa melayani lebih baik lagi.

\section{Secara Lisan (Wawancara)}

Untuk mendapatkan data primer, wawancara secara mendalam dilakukan. Narasumber wawancara dipilih melalui teknik purposive sampling dengan jumlah narasumber sebanyak 14 orang. Peneliti mewawancarai narasumber dengan data sebagai berikut: tiga orang laki-laki dan sebelas orang perempuan, dengan rentang usia 19-55 tahun. Berdasarkan asal wilayah, sebagian narasumber berasal dari kota Bandar Lampung sementara empat orang berasal dari luar kota Bandar Lampung. Narasumber dipilih secara spesifik melalui jalur pertemanan dan hubungan kerabat peneliti dengan diawali dengan bertanya melalui jalur komunikasi personal antara peneliti dengan narasumber tentang pernah tidaknya narasumber menginap di hotel bintang empat di Kota Bandar Lampung. Durasi ketika peneliti melakukan wawancara dengan narasumber berkisar antara rentang 11 sampai 28 menit.

Dari hasil pengambilan data primer berupa wawancara, peneliti dapat membandingkan beberapa elemen yang memberi kepuasan dan ketidakpuasan bagi tamu hotel bintang empat di Bandar Lampung, dimana terdapat 22 elemen yang terdiri dari 13 pemberi kepuasan, yaitu sikap dan kinerja staf, lokasi, kamar, atmosfer, fasilitas, pelayanan, harga, makanan, keamanan, rekreasi dan hiburan, arsitektur, kebersihan, standar, dan 9 pemberi ketidakpuasan, yaitu sikap dan kinerja staf, kebersihan, pelayanan, makanan, kamar, fasilitas, atmosfer, lokasi dan standar.

\section{Kepuasan Tamu}

Setelah mengetahui adanya 13 elemen yang dapat memberikan kepuasan untuk tamu, selanjutnya peneliti menghitung persentase dari setiap elemen, dimana didapatkan hasil bahwa atmosfer merupakan elemen yang paling sering disebutkan oleh tamu dalam memberikan kepuasan, dengan persentase $13,14 \%$, setelah itu sikap dan kinerja staf di $10,22 \%$, lalu rekreasi \& hiburan di 9,49\%, selanjutnya terdapat tiga pemberi kepuasan yang memiliki nilai persentase yang sama di 8,76\% yaitu fasilitas, pelayanan, dan arsitektur, selanjutnya ada makanan di $8,03 \%$, lalu terdapat tiga elemen lagi yang memiliki persentase sama di 
7,30\% yaitu lokasi, kamar, dan kebersihan. Setelah itu terdapat lagi dua elemen dengan persentase 4,38\% yaitu keamanan dan standar, serta yang terakhir kepuasan dengan nilai persentase terendah di 2,19\% yaitu harga. Salah satu elemen biasanya jarang disoroti dalam memberikan kepuasan bagi tamu, tetapi baik secara lisan dan tertulis dapat memberikan kepuasan adalah arsitektur, dimana tamu merasa puas ketika hotel memiliki bangunan yang modern, terutama di bagian lobi. Elemen ini juga disebutkan di penelitian lain bahwa arsitektur lobi akan terasa menyenangkan karena adanya elemen pencahayaan, warna, tata letak, dan furnitur yang baik (Triana, Kusumah, \& Marhanah, 2019).

\section{Ketidakpuasan Tamu}

Selanjutnya peneliti juga melakukan elemen yang sama untuk ketidakpuasan tamu, dimana setelah mendapatkan adanya 9 elemen pemberi ketidakpuasan, peneliti juga menghitung persentase dari setiap elemen dan didapatkan sikap dan kinerja staf dengan persentase tertinggi di $25,93 \%$, lalu ada kamar di $22,22 \%$, disusul dengan lokasi di $11,11 \%$, ada fasilitas di $9,26 \%$, selanjutnya terdapat juga ketidakpuasan dengan nilai persentase yang sama di $7,41 \%$ yaitu kebersihan, pelayanan, dan atmosfer, setelah itu ada standar di 5,55\%, dan yang terakhir yaitu makanan di $3,70 \%$ dengan nilai persentase terendah.

Dari semua elemen-elemen pemberi kepuasan dan ketidakpuasan, terdapat 9 elemen yang memiliki kesamaan antara kepuasan dan ketidakpuasan pada tamu hotel bintang empat di Bandar Lampung, yaitu atmosfer, sikap dan kinerja staf, fasilitas, pelayanan, makanan, lokasi, kamar, kebersihan, dan standar. Selain itu, peneliti juga menemukan bagaimana cara narasumber melalui wawancara menyampaikan kepuasan dan ketidakpuasan yang mereka rasakan. Peneliti melihat dan memiliki asumsi bahwa ketika seseorang menyampaikan secara lisan tentang apa yang dirasakan setelah menginap di sebuah hotel, tamu cenderung menyampaikannya secara jelas dan detail. Namun, ketika menyampaikan secara lisan, tamu dirasa lebih sering menyampaikan kepuasan dibandingkan ketidakpuasan. Elemen ini diduga karena tamu merasa bahwa secara keseluruhan, hotel bintang empat di Bandar Lampung memang sudah sesuai dengan kriteria dan standar hotel berbintang empat pada umumnya dan tamu tidak segan untuk mengapresiasi secara langsung. Untuk itu, diharapkan untuk pihak manajemen hotel bintang empat di Bandar Lampung agar secara berkala melakukan survei secara langsung kepada tamu yang sedang menginap untuk mengetahui kepuasan dan ketidakpuasan yang dirasakan sehingga bisa mempertahankan elemen yang sudah baik dan memperbaiki elemen yang dianggap masih kurang.

\section{Komparasi Hasil yang disampaikan Secara Ter- tulis (Ulasan Online) dan Lisan (Wawancara)}

Setelah mengetahui kepuasan dan ketidakpuasan tamu pada hotel bintang empat di Bandar Lampung, pada penelitian ini peneliti juga ingin melihat dan membandingkan hasil kepuasan dan ketidakpuasan yang terbentuk, serta melihat apakah ada perbedaan tentang cara tamu menyampaikan kepuasan dan ketidakpuasannya ketika disampaikan secara tertulis melalui ulasan online dan secara lisan melalui wawancara.

Dari data sekunder secara tertulis berupa pengambilan 104 ulasan online dari situs TripAdvisor dan Google Review serta data primer secara lisan berupa hasil wawancara dengan 14 narasumber, ditemukanlah beberapa hasil yang bisa dibandingkan, seperti hasil dari ulasan online ditemukan 19 elemen yang terdiri dari 11 elemen yang dapat memberi kepuasan dan delapan elemen yang memberi ketidakpuasan, sedangkan hasil wawancara mendapat temuan berupa 22 elemen yang terdiri dari 13 elemen tentang kepuasan dan sembilan elemen tentang ketidakpuasan. Untuk lebih jelasnya, perbandingan elemen-elemen yang bisa memberi kepuasan dan ketidakpuasan untuk tamu jika disampaikan secara tertulis melalui ulasan online dan secara lisan melalui wawancara dipaparkan melalui Gambar 1.

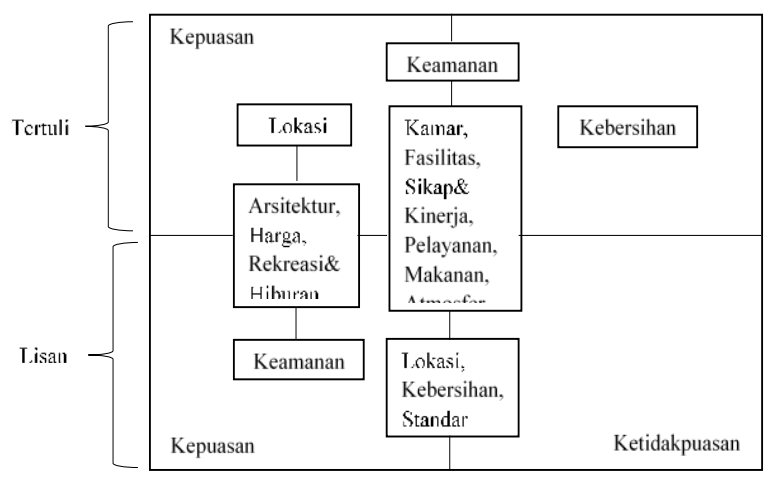

Gambar 1. Hasil Wawancara

Dari elemen-elemen tersebut, hasil ulasan online menunjukkan bahwa terdapat empat elemen yang hanya berlaku sebagai pemberi kepuasan saja, yaitu lokasi, arsitektur, rekreasi dan hiburan, serta harga, sedangkan hasil wawancara juga memiliki empat penentu yang hanya berlaku sebagai pemberi kepuasan saja, tetapi terdapat satu elemen yang berbeda jika dibandingkan, yaitu lokasi digantikan keamanan. 
Selain itu, hasil ulasan online juga menunjukkan bahwa terdapat satu penentu yang hanya berlaku sebagai penentu ketidakpuasan, yaitu kebersihan, sedangkan dari hasil wawancara justru banyak narasumber yang mengapresiasi kebersihan hotel yang terjaga sehingga terbentuklah elemen yang bisa memberi kepuasan yang baru, yaitu kebersihan.

Lalu jika berbicara mengenai elemen yang disaat bersamaan bisa menjadi kepuasan dan ketidakpuasan jika dilihat dari hasil ulasan online, yaitu terdapat tujuh elemen, diantaranya atmosfer, fasilitas, sikap dan kinerja staf, kamar, pelayanan, makanan, dan keamanan. Sedangkan untuk hasil wawacara terdapat sembilan elemen yang merupakan penentu kepuasan dan juga ketidakpuasan, yaitu atmosfer, fasilitas, sikap dan kinerja staf, kamar, pelayanan, makanan, lokasi, kebersihan, dan standar. Elemen ini diduga bisa terjadi karena memang atribut hotel yang paling sering diketahui dan berkaitan dengan pengalaman tamu saat menginap adalah elemen-elemen tersebut, sehingga banyak tamu yang menyampaikannya, baik sebagai kepuasan maupun ketidakpuasan.

Setelah itu terdapat satu elemen lagi yang baru terbentuk dan merupakan pemberi kepuasan sekaligus ketidakpuasan untuk tamu, yaitu standar yang berbicara tentang ukuran yang dipakai sebagai patokan dalam menjalani aturan yang berlaku di hotel. Elemen ini diduga mengapa baru tersampaikan ketika tamu diwawancarai secara langsung, karena jika dilihat dari data informan, kebanyakan narasumber yang peneliti wawancarai adalah orang-orang yang sudah sering menginap di banyak hotel bintang empat, baik di Bandar Lampung maupun di luar kota Bandar Lampung, sehingga mereka cenderung membandingkan pengalaman menginap mereka di satu tempat dengan tempat yang lain sehingga mengakibatkan narasumber mulai menyampaikan tentang standar bintang hotel empat pada umumnya yang sudah seharusnya diterapkan.

Selain itu, berdasarkan hasil temuan baik disampaikan secara tertulis melalui ulasan online maupun secara lisan melalui wawancara ditemukan kesamaan tentang elemen yang elemen yang paling sering disebutkan oleh tamu dalam memberikan kepuasan, yaitu atmosfer. Elemen ini menunjukkan dimana tamu hotel bintang empat di Bandar Lampung lebih mengutamakan suasana yang nyaman, tenang, asri, dan sejuk sebagai tempat mereka untuk beristirahat. Tamu juga akan semakin puas ketika dari jendela kamarnya bisa mendapati pemandangan yang indah, berupa laut, pantai, gunung, atau kota yang tentu saja bisa memanjakan mata. Elemen tersebut akan menambah kenyamanan dan rasa puas untuk tamu.
Sedangkan untuk kepuasan yang jarang disebutkan dari hasil ulasan online, ada pada keamanan, lalu dari hasil wawancara, yaitu harga. Ketidakpuasan yang paling sering disebutkan dari hasil ulasan online, yaitu kamar, sedangkan dari hasil wawancara, yaitu sikap dan kinerja staf. Sedangkan ketidakpuasan yang jarang disebutkan dari hasil ulasan online, yaitu keamanan dan dari hasil wawancara, yaitu makanan. Semua penjelasan mengenai elemen tersebut sudah dijelaskan pada poin-poin sebelumnya.

Setelah melihat adanya perbandingan tentang elemen-elemen yang bisa memberikan kepuasan dan ketidakpuasan bagi tamu secara tertulis dan lisan, peneliti juga menemukan perbandingan tentang cara tamu menyampaikan kepuasan dan ketidakpuasannya jika disampaikan melalui tulisan dan secara lisan. Ketika menyampaikan melalui tulisan, tamu cenderung menyampaikannya secara singkat, hanya berfokus pada poin-poin penting, jika berbicara tentang kepuasan. Namun tidak sedikit dari tamu yang mau menguraikan secara lengkap pengalaman kurang menyenangkan yang dialaminya, agar pembaca lain bisa mempertimbangkan elemen tersebut. Elemen ini juga didukung bahwa tidak semua orang mau menghabiskan banyak waktu hanya untuk menuliskan sebuah ulasan, karena belum semua orang merasa bahwa ulasan itu merupakan sesuatu elemen yang penting.

Jika berbicara tentang tamu yang menyampaikan kepuasan dan ketidakpuasannya secara lisan, tamu dirasa lebih detail menyampaikan keseluruhan pengalamannya. Namun, ketika menyampaikan secara lisan, tamu cenderung lebih sering menyampaikan kepuasan dibandingkan ketidakpuasan. Elemen ini diduga karena tamu merasa bahwa secara keseluruhan, hotel bintang empat di Bandar Lampung memang sudah sesuai dengan kriteria dan standar hotel berbintang empat pada umumnya dan tamu tidak segan untuk mengapresiasi secara langsung. Selain itu, banyak narasumber yang menunjukkan ketertarikannya ketika peneliti meminta bantuan untuk melakukan wawancara, dimana mereka merasa menemukan tempat yang tepat untuk menyampaikan apresiasi sekaligus keluhan yang mereka alami ketika mereka tidak sempat menyampaikannya secara langsung kepada pihak hotel dan berharap bahwa penelitian ini akan dibaca oleh beberapa pihak hotel yang terkait. Untuk itu, peneliti memiliki saran untuk pihak manajemen hotel bintang empat di Bandar Lampung agar melakukan survei secara berkala dan menanyakan langsung kepada tamu yang sedang menginap untuk mengetahui kepuasan dan ketidakpuasan yang mereka rasakan sehingga hotel bisa mempertahankan elemen yang sudah baik dan memperbaiki elemen yang dianggap masih kurang. 


\section{SIMPULAN DAN SARAN}

Dari dua hasil temuan yang sudah peneliti lakukan untuk mengetahui dan membandingkan kepuasan dan ketidakpuasan tamu secara tertulis dan lisan pada hotel bintang empat di Bandar Lampung, yaitu melalui hasil ulasan online dan wawancara, peneliti memiliki beberapa simpulan, yaitu penelitian dari hasil 104 ulasan online yang berasal dari situs ulasan Tripadvisor dan Google Review membentuk 19 elemen yang terdiri dari 11 elemen kepuasan dan delapan elemen ketidakpuasan dimana tujuh diantaranya yang merupakan elemen pemberi kepuasan sekaligus ketidakpuasan bagi tamu. Ketujuh element tersebut yaitu atmosfer, fasilitas, sikap dan kinerja staf, kamar, pelayanan, makanan, dan keamanan, lalu terdapat empat elemen yang hanya berlaku untuk penentu kepuasan saja, yaitu arsitektur, lokasi, harga, serta rekreasi dan hiburan dan satu elemen yang hanya berlaku sebagai ketidakpuasan tamu saja, yaitu kebersihan. Elemen sikap dan kinerja karyawan, serta kualitas produk selaras dengan faktor utama yang perlu diperhatikan dalam kaitannya dengan kepuasan konsumen menurut Lupiyoadi (2001). Di samping itu, penelitian dari hasil wawancara dengan 14 narasumber yang telah memenuhi kriteria menghasilkan 22 elemen yang terdiri dari 13 kepuasan dan sembilan ketidakpuasan. Dari hasil wawancara ini jika dibandingkan dengan hasil ulasan online terdapat sedikit perbedaan, yaitu terdapat dua elemen tentang kepuasan yang baru terbentuk, yaitu kebersihan dan standar, lalu mengurangi satu elemen mengenai ketidakpuasan dari hasil ulasan online yaitu keamanan, namun juga menambah dua elemen ketidakpuasan dari hasil wawancara, yaitu lokasi dan standar, dimana terdapat sembilan elemen yang merupakan pemberi kepuasan juga ketidakpuasan bagi tamu, seperti atmosfer, sikap dan kinerja staf, fasilitas, pelayanan, makanan, lokasi, kamar, kebersihan, dan standar, lalu empat elemen yang hanya berlaku sebagai pemberi kepuasan, seperti rekreasi dan hiburan, arsitektur, keamanan, dan harga, serta tidak terdapat elemen yang hanya berlaku untuk ketidakpuasan tamu.

Penelitian dari 104 ulasan online menghasilkan simpulan, yaitu pemberi kepuasan yang sering disebutkan oleh tamu terletak pada atmosfer, dimana dituliskan bahwa tamu menyukai suasana yang sejuk dan pemandangan yang indah, sedangkan kepuasan yang jarang disebutkan, yaitu keamanan karena banyak tamu kurang mengalami pengalaman berkesan yang berkaitan dengan keamanan yang hotel berikan. Lalu untuk ketidakpuasan yang sering disebutkan ada pada kamar, serta ketidakpuasan yang jarang disebutkan, yaitu keamanan. Temuan ini mirip dengan penelitian-penelitan sebelumnya dimana keluhan terbentuk karena keamanan (Heung, 2000) dan kamar serta fasilitasnya (Dolnicar, 2002).

Selanjutnya hasil penelitian melalui wawancara membuat peneliti bisa menggali secara lebih dalam. Hasil wawancara dengan 14 narasumber menghasilkan simpulan, yaitu elemen pemberi kepuasan yang paling sering disebutkan juga terletak pada atmosfer dimana dijelaskan bahwa tamu sangat mengapresiasi ketika mendapat kamar dengan view laut, gunung, atau kota Bandar Lampung, sedangkan kepuasan yang jarang disebutkan yaitu harga, karena harga yang dibayarkan oleh tamu masih dalam tarif yang standar sehingga tamu dirasa tidak perlu terlalu mengapresiasi harga yang sudah dibayarkan. Temuan ini berbeda dengan penelitian sebelumnya dari Heung (2000) yang menemukan bahwa nilai uang justru adalah salah satu faktor penyebab ketidakpuasan utama. Hasil penelitian ini menunjukkan bahwa ketidakpuasan yang sering disebutkan ada pada sikap dan kinerja staf karena masih ditemui beberapa staf yang belum bisa bersikap dan bekerja dengan baik, serta ketidakpuasan yang jarang disebutkan, yaitu makanan.

Selain itu, kesimpulan yang bisa peneliti ambil adalah elemen yang bisa memberikan kepuasan dan ketidakpuasan untuk tamu lebih banyak ditemukan saat disampaikan secara lisan. Ketika menyampaikan melalui tulisan, tamu cenderung menyampaikannya secara singkat, tetapi ketika menyampaikan kepuasan dan ketidakpuasannya secara lisan, tamu dirasa lebih detail menyampaikan keseluruhan pengalamannya. Namun, ketika menyampaikan secara lisan, tamu cenderung lebih sering menyampaikan kepuasan dibandingkan ketidakpuasan. Elemen ini diduga karena tamu merasa bahwa secara keseluruhan, hotel bintang empat di Bandar Lampung memang sudah sesuai dengan kriteria dan standar hotel berbintang empat pada umumnya dan tamu tidak segan untuk mengapresiasi secara langsung. Untuk itu, diharapkan untuk pihak manajemen hotel bintang empat di Bandar Lampung agar secara berkala melakukan survei secara langsung kepada tamu yang sedang menginap untuk mengetahui kepuasan dan ketidakpuasan yang dirasakan sehingga bisa mempertahankan elemen yang sudah baik dan memperbaiki elemen yang dianggap masih kurang

Semua simpulan yang didapatkan sesuai dengan asumsi peneliti yang mempercayai bahwa adanya perbedaan kepuasan dan ketidakpuasan tamu, baik yang disampaikan secara tertulis melalui ulasan dan secara lisan melalui wawancara dan peneliti bisa menggali dan mengetahui secara lebih dalam tentang keseluruhan pengalaman tamu saat menginap di hotel bintang empat di Bandar Lampung. 
Berdasarkan hasil penelitian ini dapat terlihat bahwa elemen-elemen yang dikeluhkan oleh tamu hotel lebih banyak disampaikan melalui lisan dibandingkan melalui tulisan atau komentar. Berkaca dari temuan ini, para praktisi perlu untuk secara aktif mendapatkan masukan secara lisan kepada tamu melalui bertanya atau berdiskusi, dan jangan hanya mengandalkan feedback tertulis melalui komentar di tripadvisor atau di platform Online Travel Agent (OTA) lainnya.

\section{DAFTAR REFERENSI}

Artanti, Y., \& Lestari, N. (2010). "Pengaruh Penanganan Keluhan Terhadap Loyalitas Nasabah Pt. Bank Muamalat Indonesia,Tbk. Dengan Kepuasan Nasabah Sebagai Variabel Perantara (Studi pada Nasabah Bank Muamalat Cabang Surabaya). Benefit Jurnal Manajemen dan Bisnis, 6674.

Berezina, K., Bilgihan, A., Cobanoglu, C., \& Okumus, F. (2016). Understanding satisfied and dissatisfied hotel customers: text mining of online hotel reviews. Journal of Hospitality Marketing \& Management, 25(1), 1-24.

Budiman, B. (2018, 01 13). Pariwisata Lampung Kian Memikat. Retrieved from Lampung.antaranews.com: https://lampung.antaranews.com/ berita/302002/pariwisata-lampung-kian-memikat.

Dolnicar, S. (2002). Business Travellers' Hotel Expectations and Disappointments: A Different Perspective to Hotel Attribute Importace Investigation. Asia Pacific Journal of Tourism Research, 7, 29-35.

Emir, O. (2011). Customer Complaints and Complaint Behavior in Turkish Hotel Restaurants: An application in Lara and Kundu areas of Antalaya. African Journal of Business Management, Academic Journals.

Gretzel, U., \& Yoo, K. (2008). Use and Impact of Online Travel Reviews. Information and Communication Technologies in Tourism, 35-46.

Heung, V. (2000). Satisfaction Levels of Mainland Chinese Travelers with Hong Kong Hotel Services. International Journal of Contemporary Hospitality Management, 12, 308-315.
Kotler, P., \& Keller, K. (2008). Manajemen Pemasaran (Edisi Ketiga Belas). Jakarta: PT. Indeks.

Kotler, P. (2000). Manajemen Pemasaran. Jakarta: PT. Prenhallindo.

Lam, S., \& Tang, C. (20013). Motivation Of Survey Employees in Construction Projects. Journal of Geospital Engineering.

Lupiyoadi. (2001). Manajemen Pemasaran Jasa Teori dan Praktek. Jakarta: Salemba-Empat.

Palupi, R., Kusumah, A., \& Rosita. (2018). Analisis Komparasi Persepsi Atribut Kualitas Restoran Antara Pelanggan yang Puas Dengan Pelanggan yang Kurang Puas di Restoran Jepang All You Can Eat. Journal of Indonesian Tourism, Hospitality and Recreation.

Redaksi. (2017, 11 09). Lampung Catat Prestasi, Kunjungan Wisatawan Nusatara Tahun 2017 Kalahkan Bali. Retrieved from Lensalampung. com: http://lensalampung.com/go/lampungcatat-prestasi-kunjungan-wisatawan-nusantaratahun-2017-kalahkan-bali/

Rosita, Marhanah, S., \& Wahadi, W. (2016). Pengaruh Fasilitas Wisata dan Kualitas Pelayanan Terhadap Kepuasan Pengunjung di Taman Margasatwa Ragunan Jakarta. Jurnal Manajemen Resort dan Leisure.

Tjiptono, F., \& Chandra, G. (2011). Service, Quality and Satisfaction (Edisi Ketiga). Yogyakarta: Andi.

Triana, D., Kusumah, A., \& Marhanah, S. (2019). The Influence of Atmospheric Elements on The Overall Guest Impression: The Case of Lobbies in Three Star Hotels in Bandung City. Advances in Social Science, Education and Humanities Research.

Utami, N. (2018, 5 21). Empat Metode Mengukur Kepuasan Pelanggan. Retrieved from Jurnal.id: https://www.jurnal.id/id/blog/2018-ketahui-4metode-mengukur-kepuasan-pelanggan/

Vela'zquez, Beatriz, M., Marı'a, F., Irene, G., \& Gloria, B. (2010). Causes For Complaining Behaviour Intentions: The Moderator Effect of Previous Customer Experience of The Restaurant. Journal of Service Marketing, 532-545.

Xiang, Z., \& Gretzel, U. (2010). Role of social media in online travel information search. Tourism management, 31(2), 179-188. 